\title{
Emerging Market Portfolio Flows: The Role of Benchmark-Driven Investors
}




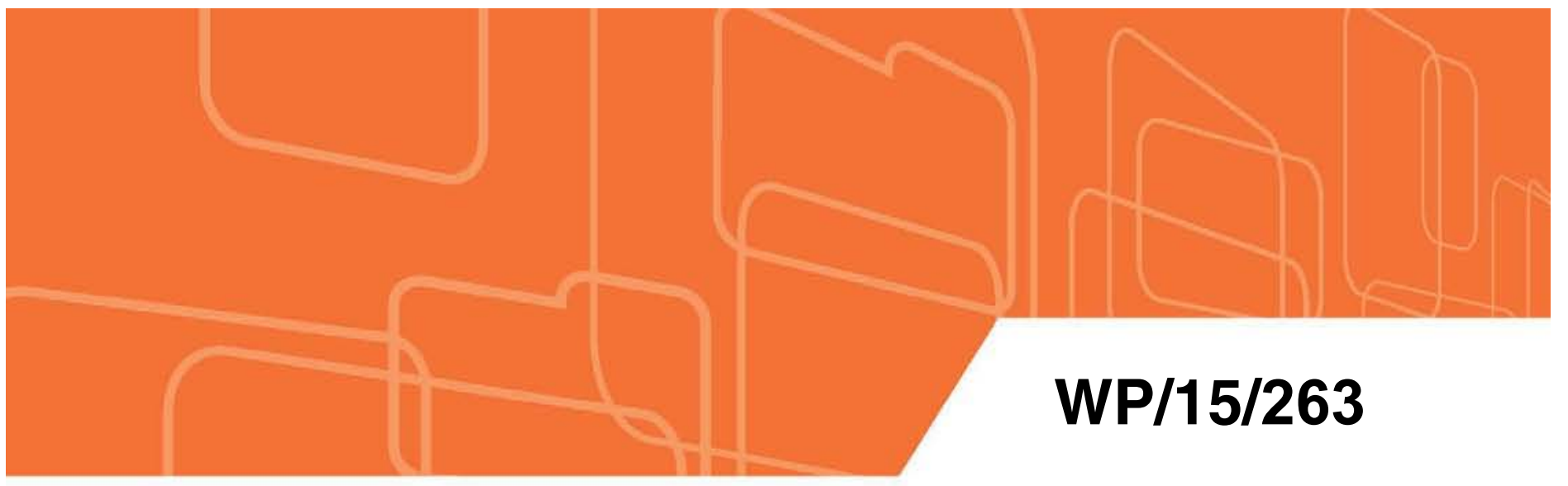

\section{Emerging Market Portfolio Flows: The Role of Benchmark-Driven Investors}

by Serkan Arslanalp and Takahiro Tsuda

I N T ER N A T I O N A L M O NETAR Y FU N D 


\title{
IMF Working Paper
}

Monetary and Capital Markets Department

\section{Emerging Market Portfolio Flows: The Role of Benchmark-Driven Investors ${ }^{1}$ \\ Prepared by Serkan Arslanalp and Takahiro Tsuda}

Authorized for distribution by Matthew Jones

December 2015

\begin{abstract}
IMF Working Papers describe research in progress by the author(s) and are published to elicit comments and to encourage debate. The views expressed in IMF Working Papers are those of the author(s) and do not necessarily represent the views of the IMF, its Executive Board, or IMF management.
\end{abstract}

\begin{abstract}
Portfolio flows to emerging markets (EMs) tend to be correlated. A possible explanation is the role global benchmarks play in allocating capital internationally, the so-called "benchmark effect." This paper finds that benchmark-driven investors indeed play a large role in a key segment of the market- the EM local currency government bond market-, accounting for more than one third of total foreign holdings as of end-2014. We find that the prominence of these investors declined somewhat after the May 2013 taper tantrum, but remain high. This distinction is important in understanding the drivers of EM capital flows and their sensitivity to different types of shocks. In particular, a high share of benchmark-driven investors may result in capital flows that are more sensitive to global shocks and less sensitive to country factors.
\end{abstract}

JEL Classification Numbers: F3, G01, G11

Keywords: International Finance, Financial Crises, Portfolio Choice, and Investment Decisions

Author’s E-Mail Addresses: sarslanalp@imf.org; takahiro.tsuda@mof.go.jp

\footnotetext{
${ }^{1}$ Takahiro Tsuda was formerly at the International Monetary Fund. We are grateful to Michael Trounce at Standard Chartered for sharing his insights and expertise on tracking portfolio flows to EMs. We thank Tamim Bayoumi, Eugenio Cerutti, Fabio Cortes, Phil de Imus, Greetje Everaert, Thomas Harjes, Daniela Klingebiel, Peter Lindner, Rodolfo Maino, Ken Miyajima, Evan Papageorgiou, Guilherme Pedras, Damien Puy, Christian Saborowski, Serdar Saginda, Miguel Savastano, and Jeffrey Williams for helpful comments and suggestions. Martin Edmonds and Shamir Tanna provided excellent research assistance. All remaining errors are our own.
} 


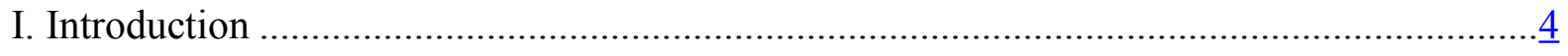

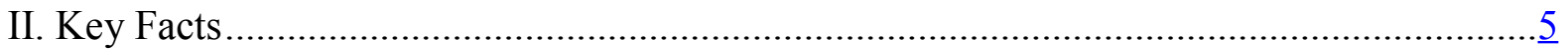

III. Estimating Benchmark Use.................................................................................. $\underline{8}$

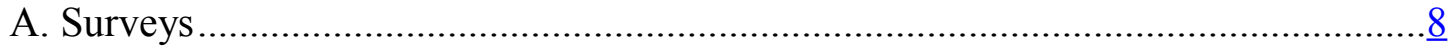

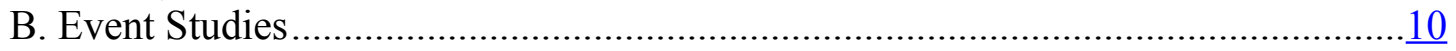

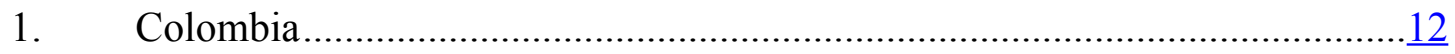

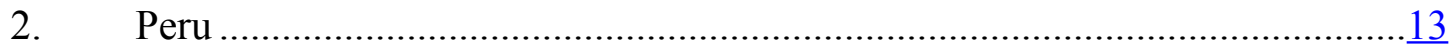

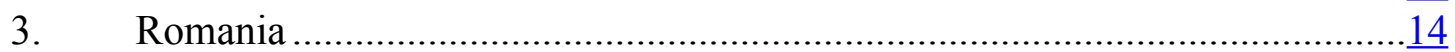

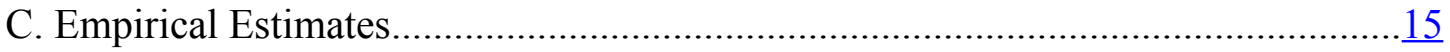

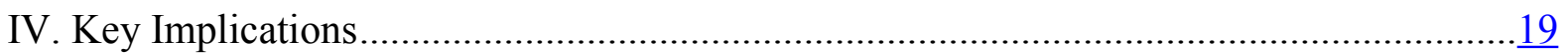

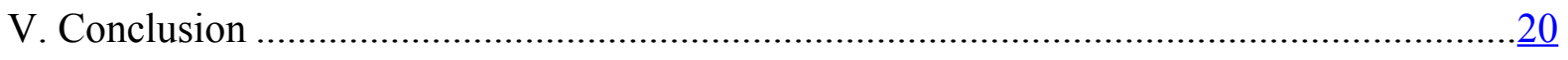

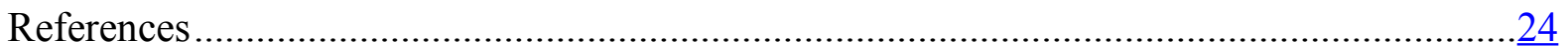

Tables

1. Assets Under Management Benchmarked to the J.P. Morgan EM Bond Indices ................. $\underline{8}$

2. Colombia: Estimated Benchmark-Driven Foreign Investor Base ................................12

3. Peru: Estimated Benchmark-Driven Foreign Investor Base .......................................13

4. Romania: Estimated Benchmark-Driven Foreign Investor Base ...................................14

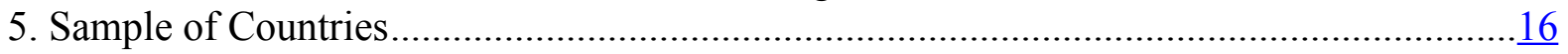

Figures

1. EM Local-Currency Government Debt Securities: Foreign Holdings .............................. $\underline{5}$

2. Emerging Markets Experiencing Significant Foreign Flows......................................

3. Portfolio Flows to Emerging Markets..................................................................... 6

4. Colombia: Change in Country Weight and Foreign Flows, 2014 ................................... 12

5. Peru: Change in Country Weight and Foreign Flows, 2014 .........................................13

6. Romania: Change in Country Weight and Foreign Flows, 2014 ....................................14

7. EM Local-Currency Government Debt Markets, End-2014 ........................................16

8. EM Local-Currency Government Bond Markets: Country Shares, End-2014 ..................17

9. Foreign Holdings of EM Local-Currency Government Debt, 2010-15Q2 ......................17

10. Comparison of Empirical Estimates with Other Data Sources ....................................18

11. EM Local-Currency Government Debt Markets: Type of Foreign Holdings....................18

12. EM Local-Currency Government Debt Markets: Selected Indictors .............................19

Annex Figures

1. EM Local-Currency Government Debt: Type of Foreign Holdings, 2010-15Q2 ...............21 


\section{INTRODUCTION}

Foreign investors held about a trillion dollars of emerging market (EM) government debt as of end-2014. According to our estimates, most of these investments -80 percent of the total-were intermediated through global asset managers, while the rest belonged to foreign banks and foreign central banks (Arslanalp and Tsuda 2014). Given the significant role asset managers play in these markets, it is important to understand what drives their investment strategies. This has also been the subject of recent work examining the drivers of capital flows to EMs (Cerutti et al. 2015, IMF 2014, Miyajima and Shim 2014, Raddatz et al. 2015).

In this paper, we distinguish between two types of foreign investments in EM local currency bond markets: benchmark-driven and unconstrained. We define benchmark-driven investors as those that invest in countries through a fund that either tracks or closely follows a flagship benchmark index. In the case of EM local currency bond markets, that benchmark is usually the J.P. Morgan Government Bond Index-Emerging Markets (GBI-EM), which has a predefined list of countries and securities. In contrast, unconstrained investors are those that can invest in countries without being restricted by index considerations.

This differentiation of the investor base is somewhat different from the distinction between passive and active funds, or retail and institutional investors. In particular, our definition of benchmark-driven investors can include "passive," "closet-index," or "weakly active" funds, using the terminology of Miyajima and Shim (2014). Similarly, it can include retail or institutional investors, depending on the investment mandate of portfolio managers.

An important advantage of looking at the investor base through this lens is that it allows us to decompose fluctuations in capital flows into a common factor (common across all counties) and a country-specific factor. It also allows us to think about different risk exposures. On the one hand, benchmark-driven investors could be seen as a stable source of funding, as they bring in capital solely because funds tracking the index have to make room in their portfolios for the country in the index (Sienaert 2012). At the same time, benchmark-driven investment strategies could be a source of vulnerability to the extent that they introduce a high degree of similarity in the behavior of asset managers investing in EMs (Raddatz et al. 2015, Miyajima and Shim 2014). In particular, they can expose countries to correlated portfolio flows, regardless of country fundamentals, and raise their sensitivity to global risk sentiment.

This paper attempts to quantify the size of benchmark-driven investors in EM local-currency bond markets, including its variation across time and countries. Gathering evidence from surveys, event studies, and empirical estimates, it finds that benchmark-driven investors represented a significant portion of EM local bond investors at end-2014: \$200-\$250 billion, or more than a third of total foreign holdings of $\$ 600$ billion. The prominence of these investors grew rapidly until it reached a peak before the May 2013 taper tantrum. We also find large cross-country variation in the relative importance of benchmark-driven investors.

The rest of the paper is organized as follows: Section II provides more background on EM portfolio flows. Section III illustrates the approaches used to estimate the pool of benchmarkdriven investors. Section IV draws out the key policy implications and Section V concludes. 


\section{KEY FACTS}

Foreign investors have become important holders of EM local bonds in recent years. Total foreign holdings of EM local-currency government bonds have risen from $\$ 200$ billion at end-2007 to $\$ 600$ billion by end-2014. Most of the foreign purchases took place during 2010-12, when advanced economy interest rates were at historic lows (Arslanalp and Tsuda 2014). Moreover, foreign holdings rose in a similar fashion across different countries. In all of the 12 EMs in the J.P. Morgan GBI-EM for which data are available, the share of foreign holdings increased steadily from 2007 until the May 2013 taper tantrum (Figure 1).

Figure 1. EM Local-Currency Government Debt Securities: Foreign Holdings (Percent of total)
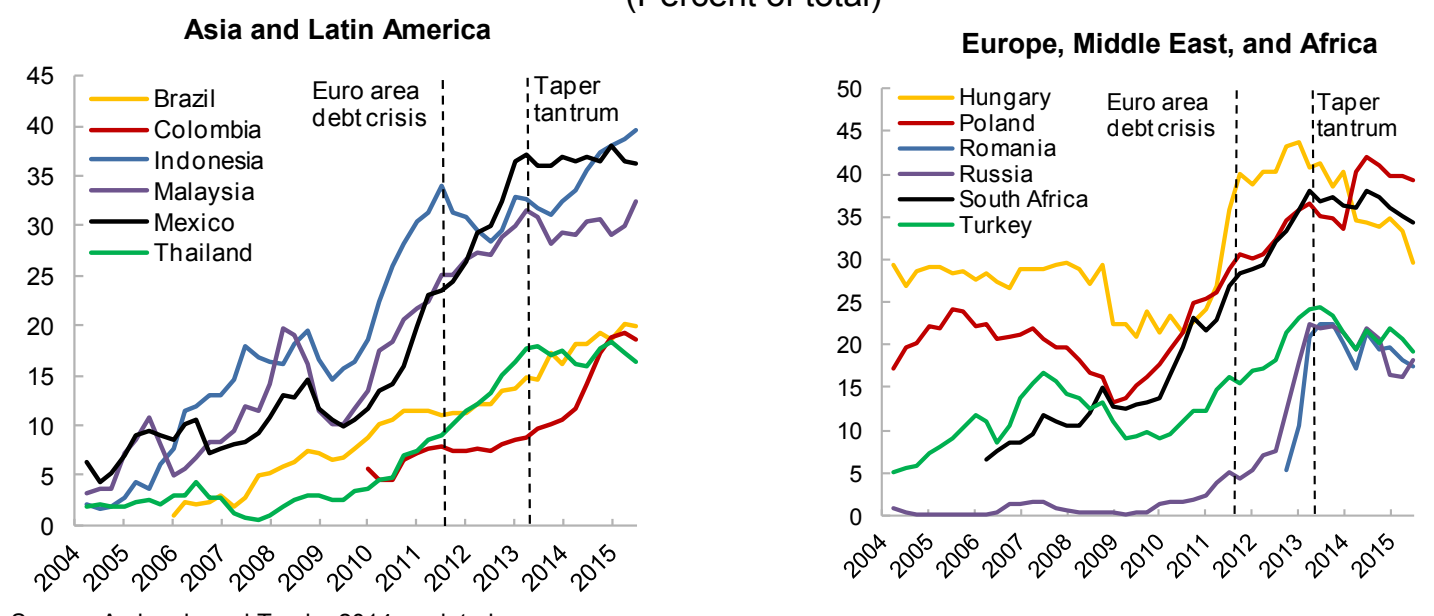

Source: Arslanalp and Tsuda, 2014, updated.

In our recent research (Arslanalp and Tsuda, 2014), we found that foreign flows to EMs exhibited three distinct phases over the past few years - before, during, and after the global financial crisis. Before the crisis (2006-07), foreign flows showed moderate differentiation among countries: some received inflows while others faced outflows. As it usually happens, this differentiation became much sharper during the crisis (2008-09). However, during the third period (2010-12), foreign flows became positive almost everywhere (Figure 2).

Figure 2. Emerging Market Debt Markets Experiencing Significant Foreign Flows (Out of total of 24 countries)

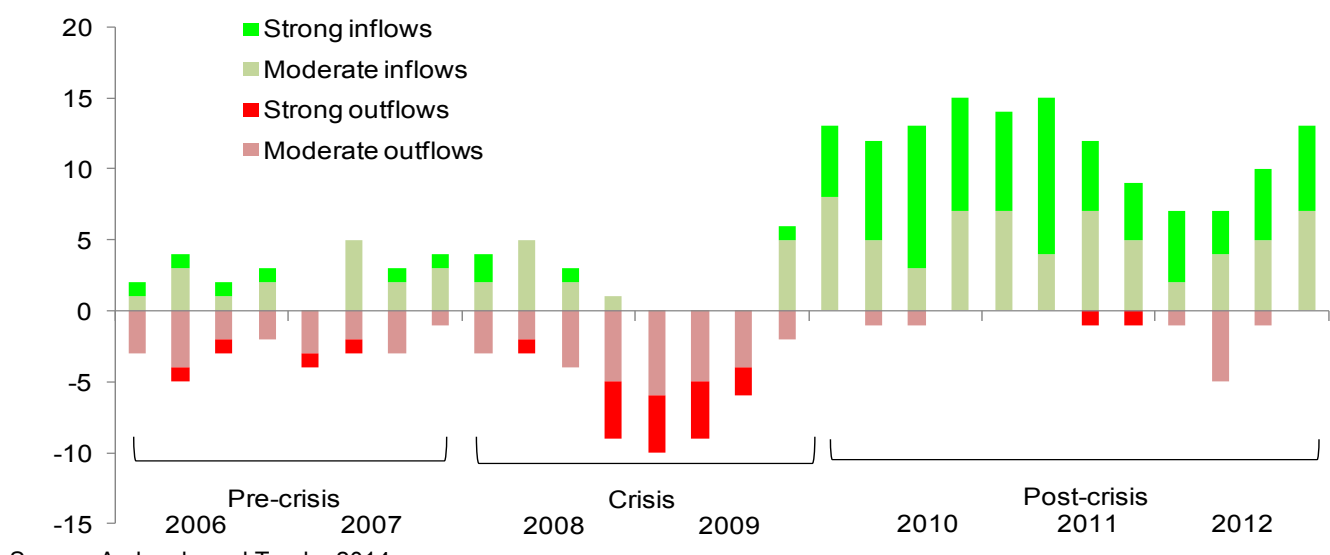

Source: Arslanalp and Tsuda, 2014
Note: Based on the relative size of net foreign purchases of government debt compared to historical norms. Strong inflows (outflows) indicate a z-score of greater (less) than $1(-1)$. The cutoff point for moderate inflows (outflows) is 0.5 (-0.5). 
Part of the steady increase in EM flows during the post-crisis period can be explained by the improving economic fundamentals of EMs. Indeed, a number of EMs reached or regained investment grade status during 2010-12: Colombia, Indonesia, Latvia, Romania, and Uruguay. Most emerging markets also weathered the crisis well, with a relatively quick return to high growth, raising expectations of currency appreciation and attracting further demand from foreign investors. At the same time, even countries whose credit ratings deteriorated or did not improve during this period continued to receive inflows.

Another explanation for the steady increase in EM flows during this period is the rising popularity of index-funds and benchmark use to invest in EMs (Raddatz et al 2015). Indeed, even after the taper tantrum, portfolio flows to EMs displayed a large degree of synchronicity (Figure 3). This similarity in the dynamics of capital flows to countries, which often differ substantially in terms of policies, quality of institutions, natural resources, and other factors, suggests that foreign demand may have been also shaped by external (or "push") factors, allocating capital independently of the respective country fundamentals (or "pull") factors.

Figure 3. Portfolio Flows to Emerging Markets (Billion U.S. dollars)

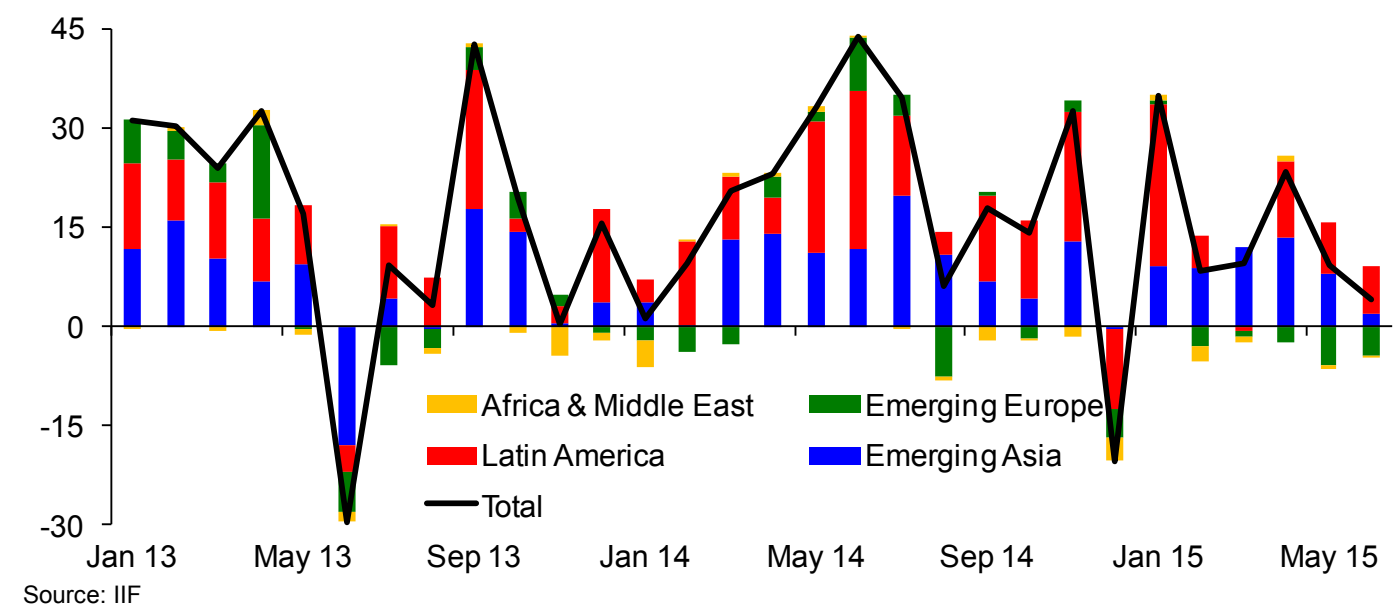

Using monthly data from 1996 to 2012 on individual mutual funds, Raddatz et al. (2015) find that benchmarks can indeed have significant effects on international investments and affect capital flows through both direct and indirect channels. ${ }^{2}$ In particular, the authors find that benchmarks explain, on average, around 70 percent of country allocations after controlling for industry, macroeconomic, and country-specific effects (or more without controls). They also predict that the benchmark effect is likely to become more important as more mutual funds follow benchmarks more passively to cut costs, increase transparency, and provide simple investment vehicles, such as index funds and exchange-traded funds (ETFs).

\footnotetext{
${ }^{2}$ Raddatz et al. (2015) define the "benchmark effect" as the channels through which "prominent international equity and bond market indices affect asset allocations and capital flows across countries," differentiating it from the role country fundamentals play in country allocations, as well as other mechanisms that can cause herding behavior by mutual funds. Studies have shown that mutual funds can propagate shocks (i) directly via their holdings (Broner, Gelos, and Reinhart, 2006), (ii) indirectly through overlapping ownership of emerging and advanced economies (Jotikasthira et al., 2012); and (iii) via fire sales (Coval and Stafford, 2007). Koepke (2015) provides an excellent summary of the vast empirical literature on the drivers of EM capital flows.
} 
Miyajima and Shim (2014) further explore the use of benchmark indices in EMs. They find that the use of benchmarks can give rise to correlated behavior on the part of even "actively" managed funds. They argue that managers of those funds tend to be evaluated by whether the returns of their investments match or exceed those of a particular benchmark index. As a result, although active managers do not necessarily fully replicate the portfolio weights of the benchmark, the career risk of short-term underperformance against their peers can induce them to form similar portfolios or to "hug" their benchmarks, increasing correlation of asset managers' portfolio choices. Moreover, they argue that a limited number of EM benchmarks, and their similar methods of construction, can further induce correlated investment behavior.

Indeed, Miyajima and Shim (2014) find that, among active EM local-currency bond funds tracked by the Emerging Market Portfolio Fund Research (EPFR) Global, the median "active share" is only 17 percent. $^{3}$ This suggests a very high (more than 80 percent) overlap in country weights between fund portfolios and the relevant benchmark. Accordingly, the authors label funds with an active share of 0-10 percent as "closet index" funds, and funds with an active share of 10-20 percent as "weakly active" funds. Based on this definition, they show that nearly 70 percent of actively managed EM bond funds tracked by EPFR Global are actually either a "closet index" or a "weakly active" fund. The measure of benchmark-driven investors that we develop in this paper would most likely include these two types of funds, because their country allocations are closely tied to the benchmark.

By helping alleviate agency problems, benchmarks allow the underlying investors to evaluate and discipline the fund managers on a short-term basis using measures such as the tracking error of the fund (Gelos 2013, Stein 2013). At the same time, to the extent that the investment strategy of these funds is pinned down by the composition of their benchmark indices, outflows from funds closely tracking an index can trigger a similar rebalancing among all countries in the index. This effect can be especially important during times of global risk aversion when redemption risk for risky assets rises. It is with this thought in mind that we try to estimate the size of benchmark-driven investors in a key part of the EM investment universe, namely the EM local-currency government bond markets.

\footnotetext{
${ }^{3}$ The active share of a fund is defined as the sum of the absolute value of deviations of the fund's country weights from those of the benchmark (Cremers and Petajisto, 2009).
} 


\section{ESTIMATING BENCHMARK USE}

In what follows, we discuss two approaches to estimate the pool of benchmark-driven investors in EM local-currency bonds markets: event studies and empirical estimation. Before this, however, it is worthwhile reporting the results of a survey conducted by J.P Morgan on the assets under management that track the J.P. Morgan GBI-EM index, one of the most widely-used EM local-currency bond indices by market participants (Box 1).

\section{A. Surveys}

J.P. Morgan conducts regular surveys to gauge the amount of assets under management that track its main benchmark indices. These are based on client surveys and include both passive funds (index funds and ETFs) and active funds that measure themselves against the GBI-EM (but have latitude to run a tracking error against the benchmark). The surveys show that, as of end-2014, around $\$ 221$ billion of assets were managed against the GBI-EM suite of indices, and \$195 billion against the GBI-EM Global Diversified index alone (Table 1).

J.P. Morgan surveys also shows that assets managed against the GBI-EM indices increased tenfold, from $\$ 21$ billion at end-2007 to $\$ 221$ billion at end-2014. Assets tracked by the GBIEM had double-digit growth rates every year during 2007-2013. Outflows from EMdedicated funds during the May 2013 taper tantrum most likely explain the slowing pace of growth starting from 2013 (J.P. Morgan, 2014). Nevertheless, the very rapid rise of assets benchmarked to the GBI-EM suggests that the size of benchmark-driven investors in EM local-currency bond markets may have also risen in recent years, something that we will explore through event studies and empirical estimation in what follows.

Table 1. Assets Under Management Benchmarked to the J.P. Morgan EM Bond Indices

(Billion U.S. dollars)

\begin{tabular}{|c|c|c|c|c|c|c|c|c|}
\hline & 2007 & 2008 & 2009 & 2010 & 2011 & 2012 & 2013 & 2014 \\
\hline Government debt (local-currency) & 21 & 36 & 55 & 79 & 146 & 195 & 217 & 221 \\
\hline GBI-EM Global Div & 6 & 14 & 36 & 57 & 127 & 175 & 197 & 195 \\
\hline GBI-EM Div & 2 & 5 & 8 & 10 & 8 & 8 & 8 & 9 \\
\hline GBI-EM Broad Div & 4 & 6 & 5 & 4 & 3 & 4 & 4 & 8 \\
\hline GBI-EM & 9 & 9 & 6 & 7 & 7 & 8 & 8 & 8 \\
\hline GBI-EM Global & 0 & 1 & 0 & 1 & 0 & 0 & 0 & 0 \\
\hline GBI-EM Broad & 0 & 0 & 0 & 0 & 1 & 1 & 0 & 0 \\
\hline Government debt (hard-currency) & 178 & 181 & 150 & 192 & 231 & 293 & 293 & 310 \\
\hline EMBI Global Div & 107 & 109 & 90 & 115 & 164 & 228 & 226 & 246 \\
\hline EMBI Global & 62 & 63 & 52 & 67 & 68 & 64 & 67 & 63 \\
\hline EMBI+ & 9 & 9 & 7 & 10 & 0 & 0 & 0 & 1 \\
\hline Corporte debt (hard-currency) & 0 & 0 & 7 & 17 & 30 & 47 & 63 & 70 \\
\hline CEMBI Broad Div & 0 & 0 & 6 & 12 & 17 & 30 & 40 & 46 \\
\hline CEMBI Diversified & 0 & 0 & 1 & 5 & 6 & 12 & 17 & 19 \\
\hline CEMBI Broad & 0 & 0 & 0 & 1 & 4 & 5 & 5 & 4 \\
\hline CEMBI & 0 & 0 & 0 & 0 & 1 & 1 & 1 & 1 \\
\hline \multicolumn{9}{|l|}{ Money market (local-currency) } \\
\hline ELMI+ & 0 & 16 & 10 & 20 & 26 & 25 & 25 & 23 \\
\hline Total & 199 & 233 & 222 & 308 & 433 & 560 & 597 & 624 \\
\hline
\end{tabular}

Source: J.P. Morgan (2014).

Notes: $\mathrm{GBI}$-EM = Government Bond Index-Emerging Markets; $\mathrm{EMBI}=$ Emerging Markets Bond Index; $\mathrm{CEMBI}=$ Corporate Emerging Markets Bond Index; ELMI = Emerging Local Markets Index. Figures for 2014 are as of end-September, 2014. 


\section{Box 1. Emerging Market Bond Indices}

The J.P. Morgan GBI-EM index is believed to be the most widely used index among EM local-currency government bond investors, along with the Barclays and Citigroup EM bond indices. Among global bond indices, the weight of EMs remains small, less than 1 percent at the country level and around 2 percent at the aggregate level.

\section{Major EM bond indices}

The J.P. Morgan Government Bond Index-Emerging Markets (GBI-EM) index was launched in 2005.There are three versions of the index (GBI-EM Broad, GBI-EM Global, and GBI-EM), and each version has a diversified overlay. The diversified version places a 10 percent cap for each country to limit concentration risk. According to J.P. Morgan, the GBI-EM Global Diversified is the most popular among the six versions - accounting for around 90 percent of all AUM benchmarked to the GB-EM suite of indices as of end-2014. The main entry requirement for the index is market accessibility. There are no minimum-rating requirements or explicit market size limits. Treasury bills and inflation-indexed bonds are not eligible for the index (only fixed-rate nominal bonds). As of end-2014, 16 countries were included in the GBI-EM Global index: Brazil, Chile, Colombia, Hungary, Indonesia, Malaysia, Mexico, Nigeria, Peru, Philippines, Poland, Romania, Russia, South Africa, Thailand, and Turkey.

The Barclays Emerging Markets Local Currency Government Index was launched in 2008. The main entry requirements are: a minimum market capitalization of $\$ 5$ billion and market accessibility. There are no minimumrating requirements. Nominal bonds and bill are eligible for inclusion, but inflation-indexed bonds are not. The index has a large overlap with the J.P. Morgan GBI-EM Global index, covering the same countries and (since March 2013) three more: the Czech Republic, Israel, and Korea. Miyajima and Shin (2014) show that comparable EM bond indices provided by J.P. Morgan and Barclays have more than an 80 percent overlap in country weights.

The Citi Emerging Markets Government Bond Index (EMGBI) was launched in 2013. The main entry requirements are: a minimum market capitalization of US\$10 billion and market accessibility. There are no minimum rating requirements. Treasury bills and inflation-indexed bonds are not eligible for inclusion. This index also has large overlap with the J.P. Morgan GBI-EM Global index. As of end-2014, the index includes all the GBIEM Global countries, except for Nigeria and Romania - two countries with small weights in the GBI-EM Global.

There are also a few regional EM bond indices, such as the HSBC Asian Local Bond Index (ALBI) and the Markit iBoxx Asian Bond Fund (ABF) Index, that invest primarily in Asia.

\section{Major global bond indices}

The Barclays Global Aggregate Index (Global AGG) tracks fixed-rate investment-grade bonds of both developed and emerging markets, with a market capitalization of \$43 trillion as of end-2014. The index was created in 1992, and historical data are available from January 1987. The Treasury sector of the Global Aggregate index tracks central government bonds issued by 37 countries in 24 currency markets, representing a total market capitalization of \$23 trillion at end-2014. The main entry requirements are: countries must have investment-grade status, based on the middle rating of Fitch, Moody's, and S\&P (or the lower rating when not all ratings are available), and "a freely traded, convertible currency with a liquid forward market that allows investors to hedge their currency exposure." As of end-2014, eight EMs have sovereign bonds included in the Barclays Aggregate index (with country weights shown in parentheses): Chile (0.01 percent), Malaysia (0.2 percent), Mexico ( 0.4 percent), Poland ( 0.2 percent), Russia ( 0.1 percent), South Africa (0.2 percent), Thailand ( 0.2 percent), and Turkey ( 0.2 percent).

The Citibank World Government Bond Index (Citi WGBI) tracks fixed-rate investment-grade sovereign bonds of both developed and emerging markets, with a market capitalization of \$20 trillion as of end-2014. The index was created in 1986, and historical data are available from December 1984. Main entry requirements are: minimum market capitalization of $\$ 50$ billion, a domestic long-term credit rating of A-/A3 by S\&P/Moody's, and no barriers to entry as reflected in policies that "actively encourage foreign investor participation." As of end-2014, there are four EMs included in the WGBI (with country weights shown in parentheses): Malaysia (0.4 percent), Mexico (0.8 percent), Poland ( 0.5 percent), and South Africa (0.4 percent). 


\section{B. Event Studies}

In this section, we present the results of three event studies that can provide further evidence on the size of the benchmark-driven investor universe as of 2014. Overall, the event studies suggest that the pool of benchmark-driven investors falls within the range of \$170-\$270 billion as of 2014 (or around $\$ 227$ billion if we take the average of the three studies), broadly in line with the results of the J.P. Morgan survey (\$221 billion).

The identification approach used in the event studies is as follows: We look for episodes in which a country's weight in the J.P. Morgan GBI-EM index rises sharply, in particular due to an increase in the nominal stock of its "index-eligible" securities. This can happen when J.P. Morgan decides that a new (or existing) government bond meets (or begins to meet) all GBI-EM inclusion criteria and announces that it will be included in the index going forward. We can think of this as an exogenous supply shock that can lead to an automatic rise in demand by benchmark-driven investors, but not by unconstrained investors, (since, by definition, those investors should not be driven by index weights). ${ }^{4}$ As a result, a technical supply-driven event as such can create foreign flows, which should be detectable in the balance of payments if there is a substantial benchmark-driven investor base.

We identify three such episodes in 2014: Colombia (April-September 2014), Peru (November 2014), and Romania (April-May 2014), in which case the weight of each country in the GBIEM increased sharply, along with a rise in the nominal stock of "index-eligible" securities. 5

Country weights may also change due to valuation effects (i.e. due to changes in market yields and exchange rates of each country in the index). For example, the weight of Russia in the GBIEM (Global Diversified) fell from 10 percent at end-March 2014 to 4.7 percent at end-March 2015, mainly due to the sharp depreciation of the ruble. This highlights the importance of separating "valuation effects" from other exogenous changes in country weights.

For that, we use the approach proposed by Raddatz et al. (2015) and separate the change in a country's weight $\left(w_{i t}\right)$ into two components: (i) the buy-and-hold component, which captures the valuation effects mentioned earlier, $w_{i t}\left(R_{i t} / R_{b t}\right)-w_{i t}$, where $R_{i t}$ and $R_{b t}$ are the total gross returns on the country's bonds and the benchmark, respectively; and (ii) the exogenous component, capturing other changes, in particular the change in the stock of index-eligible debt.

$$
w_{i t+1}-w_{i t}=\underbrace{\left.w_{i t+1}-w_{i t} * \frac{R_{i t}}{R_{b t}}\right)}_{\text {Exogenous component }}+\underbrace{\left(w_{i t} * \frac{R_{i t}}{R_{b t}}-w_{i t}\right)}_{\text {Buy-and-hold component }}
$$

\footnotetext{
${ }^{4}$ Note that these events are based on security inclusion, not country inclusion, episodes. In other words, we only consider countries that are already in the index. We avoid country inclusion events because those may have wider signaling effects that affect benchmark-driven and unconstrained investors simultaneously.

${ }^{5}$ The event window sizes are determined by the time it took for the new securities to become fully part of index.
} 
Given that a benchmark-driven investor would see the weight of country $i$ in his or her portfolio change automatically because of the buy-and-hold component, only the exogenous component of the weight change should trigger capital flows. Hence, we estimate the size of the benchmark driven investor base as follows:

$$
B_{t}=f_{i t} /\left(w_{i t+1}-w_{i t} * \frac{R_{i t}}{R_{b t}}\right)
$$

Where:

$B_{t}$ is the benchmark-driven investor base at time $t$ in U.S. dollars.

$f_{i t}$ is the net foreign purchase of country i's bonds between time $\mathrm{t}$ and $t+1$ in U.S. dollars. ${ }^{6}$

$w_{i t}$ is the weight of country $\mathrm{i}$ in the benchmark at time $t$. Here, we use the J.P. Morgan GBI-EM Global Diversified as the "representative" benchmark, given its wide use and overlap with other EM bond indices. ${ }^{7}$

$R_{i t}$ and $R_{b t}$ are the total gross returns of country $i$ 's bonds and the benchmark, respectively, from time $t$ to $t+1$.

Below, we estimate the benchmark-driven investor base $\left(\mathrm{B}_{\mathrm{t}}\right)$ using Equation 2, based on the three episodes mentioned earlier (Colombia, Peru, and Romania).

\footnotetext{
${ }^{6}$ We use the months before and after the inclusion event to measure net foreign purchases. For example, if a new bond enters the index on November 30, 2014 (following an announcement earlier in the month), we cover flows during both November and December 2014 to capture benchmark-driven purchases around the time of the event.

${ }^{7}$ Miyajima and Shim (2014) show that the J.P Morgan GBI-EM (Global Diversified) index is the most widely followed EM local bond index in the marketplace, and that there is a strong overlap between the index and other EM bond indices (see also Box 1). Moreover, the weight of EMs in global bond indices, such as Barclays Global Aggregate and Citibank WGBI, is too small to make those investors sensitive to changes in country weights (Box 1). Hence, for EMs, we treat investors tracking those global indices in the same group as unconstrained investors.
} 


\section{Colombia}

Colombia's weight in the J.P. Morgan GBI-EM index rose sharply in 2014, after J.P. Morgan announced in March 2014 that it would include five additional Colombian bonds (maturing in 2016, 2028, 2022, 2024, and 2028) in the index from end-April to end-September, in a phased manner. The inclusion increased Colombia's index-eligible debt stock (in nominal terms) by 150 percent, and raised Colombia's weight in the index by 4.45 percentage points from 3.24 percent at end-February to 7.69 percent at end-September. Using Equation 1, we estimate that 4.35 percentage points of the rise in the country weight was exogenous (i.e. due to the inclusion of the new bonds), while the rest was due to valuation effects (Table 2).

To maintain the same position on Colombia, a benchmark-driven investor would have to allocate more capital to the country beyond the valuation gains. This is in fact what was observed. Net foreign purchases of Colombian local government bonds were $\$ 7.36$ billion during March-September 2014, much more than in previous years (Figure 4). Assuming unconstrained investors did not alter their positions due to the index change, this would imply a benchmark-driven investor base of around $\$ 170$ billion at the time of the event (Table 2).

Figure 4. Colombia: Change in Country Weight and Foreign Flows, 2014

(Billion U.S. dollars; percent)

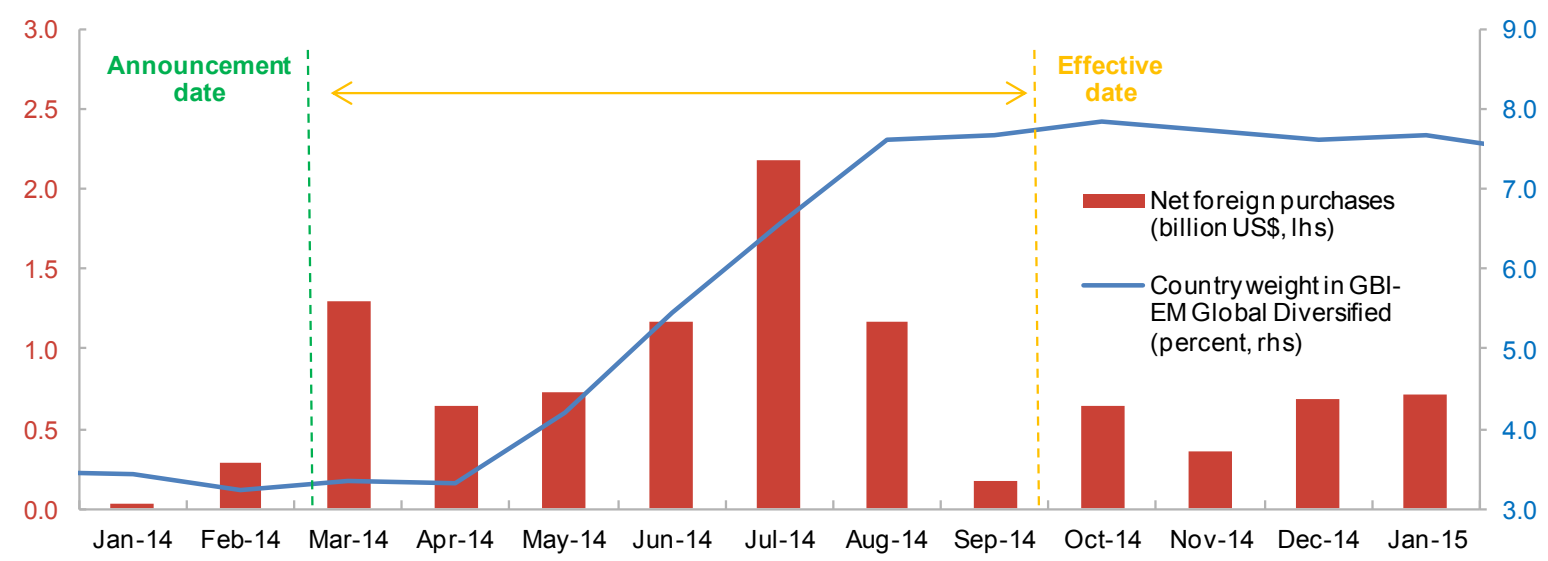

Sources: J.P. Morgan and national authorities.

Note: In March 2014, J.P. Morgan announced that it would include five additional Colombian local-currency government bonds into the GBIEM Global Diversified index in a phased manner until September 2014.

Table 2. Colombia: Event Study

\begin{tabular}{lcc}
\hline & $\begin{array}{c}\text { end-Feb } \\
2014\end{array}$ & $\begin{array}{c}\text { end-Sep } \\
2014\end{array}$ \\
\hline Country weight (GBI-EM Global Diversified) & \multicolumn{2}{c}{ (Percent) } \\
Change in country weight from Feb to Sep 2014 & 3.24 & 7.69 \\
Buy-and-hold component & 4.45 \\
Exogenous component (a) & 0.10 \\
Net foreign purchases during Mar-Sep 2014 (b) & (Billion U.S. dollars) \\
Estimated benchmark-driven investor base (c=b/a) & & 7.36 \\
\hline
\end{tabular}

Sources: J.P. Morgan, national authorities, and authors' calcualtions. 


\section{Peru}

Peru's weight in the J.P Morgan GBI-EM index rose sharply in November 2014, after a new Peruvian government bond (Peru 5.7 percent August 2020) was included in the index at endNovember 2014 (the announcement was made earlier that month). The inclusion of the 7.4 billion nuevo soles ( $\$ 2.5$ billion) bond increased Peru's index-eligible debt stock (in nominal terms) by 17 percent, and raised Peru's weight in the J.P. Morgan index by 0.39 percentage points from 1.47 percent at end-October to 1.86 percent at end-December. Using Equation 1, we estimate that 0.30 percentage points of the rise in the country weight was exogenous (i.e. due to the inclusion of the new bond), while the rest was due to valuation effects (Table 3 ).

To maintain the same position on Peru, a benchmark-driven investor would have to allocate more capital to the country beyond the valuation gains. This is in fact what was observed. Net foreign purchases of Peruvian local government bonds were $\$ 0.72$ billion during NovemberDecember, the highest level in 2014 (Figure 5). Assuming unconstrained investors did not alter their positions due to the index change, this would imply a benchmark-driven investor base of around $\$ 240$ billion at the time of the event (Table 3).

Figure 5. Peru: Change in Country Weight and Foreign Flows, 2014

(Billion U.S. dollars; percent)

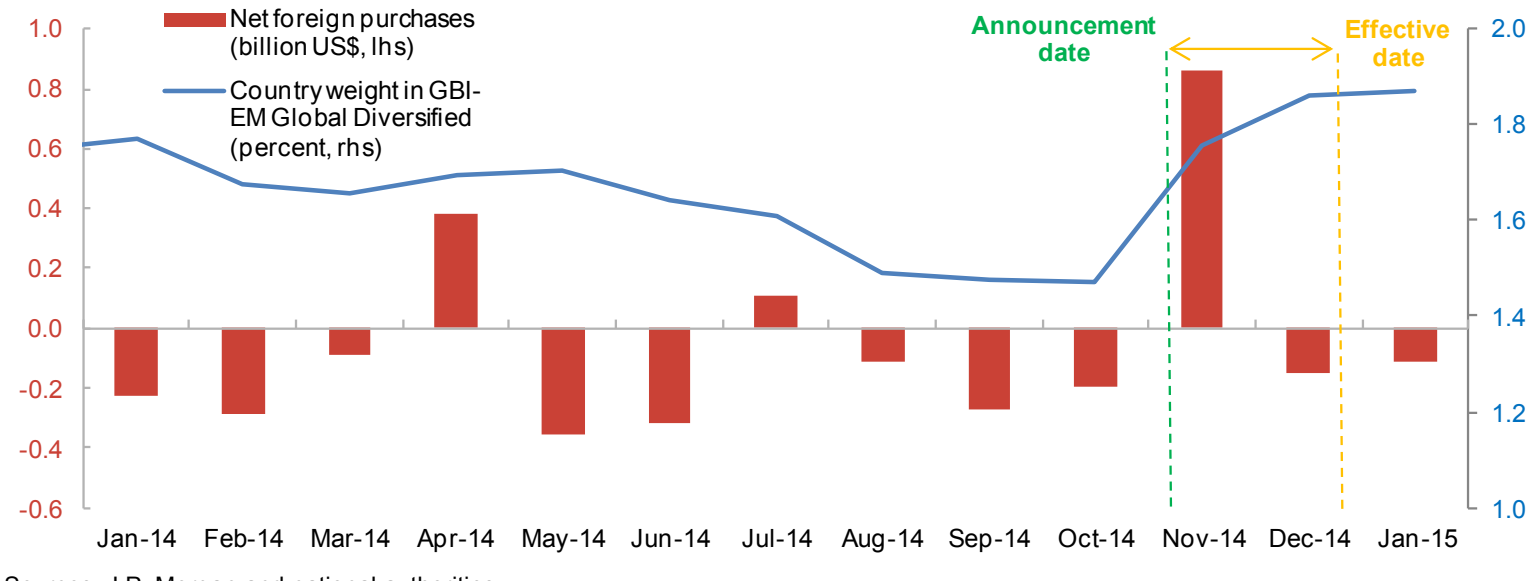

Sources: J.P. Morgan and national authorities.

Table 3. Peru: Event Study

\begin{tabular}{lcc}
\hline & $\begin{array}{c}\text { end-Oct } \\
2014\end{array}$ & $\begin{array}{c}\text { end-Dec } \\
2014\end{array}$ \\
\hline & \multicolumn{2}{c}{ (Percent) } \\
Country weight (GBI-EM Global Diversified) & 1.47 & 1.76 \\
Change in country weight from Oct to Dec 2014 & & 0.39 \\
Buy-and-hold component & 0.09 \\
Exogenous component (a) & 0.30 \\
Net foreign purchases during Nov-Dec 2014 (b) & (Billion U.S. dollars) \\
Estimated benchmark-driven investor base (c=b/a) & & 0.72 \\
\hline Sources: JP. Morgan, national authorities, and authors' calcualtions. & &
\end{tabular}




\section{Romania}

Romania's weight in the J.P. Morgan GBI-EM index rose sharply in early 2014, after two new Romanian bonds (Romania 5.6 percent November 2018, and Romania 5.95 percent June 2021) were included in the index at end-April and end-May, respectively. The inclusion of the 11.5 billion lei ( $\$ 3.5$ billion) bonds increased Romania's index-eligible debt stock (in nominal terms) by 45 percent, and raised Romania's weight in the J.P. Morgan index by 0.56 percentage points from 1.47 percent at end-March to 2.03 percent at end-June. Using Equation 1, we estimate that 0.53 percentage points of the rise in the country weight was exogenous (i.e. due to the inclusion of the new bonds), while the rest was due to valuation effects (Table 4).

To maintain the same position on Romania, a benchmark-driven investor would have to allocate more capital to the country beyond the valuation gains. This is in fact what was observed. Net foreign purchases of Romanian local government bonds were \$1.44 billion during April-June, the highest level in 2014 (Figure 6). Assuming unconstrained investors did not alter their positions due to the index change, this would imply a benchmark-driven investor base of around $\$ 270$ billion at the time of the event (Table 4).

Figure 6. Romania: Change in Country Weight and Foreign Flows, 2014

(Billion U.S. dollars; percent)

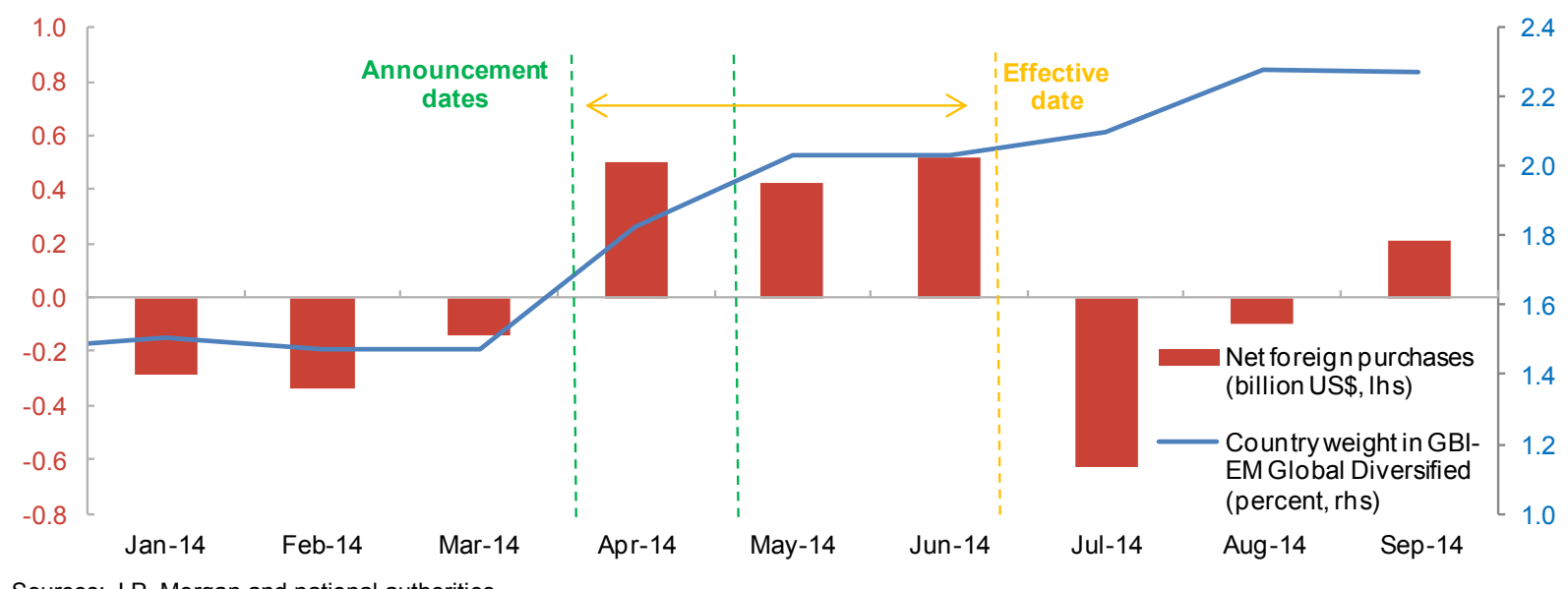

Table 4. Romania: Event Study

\begin{tabular}{lcc}
\hline & end-Mar & end-Jun \\
& 2014 & 2014 \\
\hline & \multicolumn{2}{c}{ (Percent) } \\
Country weight (GBI-EM Global Diversified) & 1.47 & 2.03 \\
Change in country weight from Mar to Jun 2014 & \multicolumn{2}{c}{0.56} \\
Buy-and-hold component & 0.03 \\
Exogenous component (a) & (Billion U.S. dollars) \\
& \multicolumn{2}{c}{0.53} \\
Net foreign purchases during Apr-Jun 2014 (b) & & 273 \\
Estimated benchmark-driven investor base (c=b/a)
\end{tabular}

Sources: J.P. Morgan, national authorities, and authors' calcualtions. 


\section{Empirical Estimates}

In this section, we present a more formal empirical analysis of the relative importance of benchmark-driven investors, both across time and across countries. In particular, we use the approach proposed by Balston and Melin (2013) to decompose foreign holdings of EM local-currency government bonds into benchmark-driven and unconstrained ones. Overall, the empirical estimates suggest that the pool of benchmark-driven investors was around \$240 billion as of end-2014, broadly in line with the results of the J.P. Morgan survey (\$221 billion) and the average estimate in event studies ( $\$ 227$ billion) presented earlier.

The Balston and Melin (2013) approach uses monthly data on foreign holdings and assumes that the pool of foreign capital invested in EM local-currency government bond markets can be divided into two pools: one benchmarked to the GBI-EM Global Diversified index, and the other benchmarked to the market capitalization of each local bond market.

Given the construction of the GBI-EM Global Diversified index, the first pool would be restricted to invest only in index-eligible debt securities (fixed-rate nominal bonds), issued only by 16 countries in the index, and with a 10 percent country limit. The second pool, in contrast, would be free to invest in other debt securities (including Treasury bills, floatingrate bonds, inflation-linked bonds), issued by both benchmark and off-benchmark EMs, and without any country limits. Hence, this second pool of investors, which would be represent our class of unconstrained investors, is assumed to allocate capital based on the overall market capitalization of bond markets, rather than the index weight of each country.

Given the difference between these two pools, the relative proportions of each pool can then be estimated over time by solving for $a_{t}$ and $b_{t}$ in the following equations:

$$
{ }_{i t}=a_{\mathrm{t}} \mathrm{W}_{\mathrm{i}, \mathrm{t}}+b_{\mathrm{t}} W_{\mathrm{i}, \mathrm{t}}+\varepsilon_{\mathrm{i}, \mathrm{t}}
$$

Subject to:

Where:

$$
a_{\mathrm{t}}+b_{\mathrm{t}}=\sum_{i=1}^{N} F_{i t}
$$

$a_{t}$ is the pool of benchmark-driven investors at time $\mathrm{t}$.

$b_{t}$ is the pool of unconstrained investors at time $\mathrm{t}$.

$w_{i, t}$ is the weight of country $i$ in the J.P. Morgan GBI-EM Global Diversified index at time $t$.

$W_{i, t}$ is the weight of country i's bond market at time $t$ based on market capitalization.

$F_{i, t}$ is the nominal amount of foreign holdings of country i's bonds at time $t$, in U.S. dollars.

$\varepsilon_{i, t}$ is the extent to which portfolio managers are over-/under- weight country $\mathrm{i}$ at time $\mathrm{t}$. 
The estimation is conducted using a constrained least squares (CLS) approach given that $a_{t}$ and $b_{t}$ should add up to total foreign holdings for each month. The sample covers the period from January 2010 to June 2015 and includes 18 countries (Table 5). Of these 18 countries, 13 are "benchmark" countries (i.e. they are in the GBI-EM Global Diversified index), while 5 are "off-benchmark" (China, the Czech Republic, India, Israel, and Korea). ${ }^{8}$ The mix of countries is meant to provide useful heterogeneity for the estimation of $a_{t}$ and $b_{t}$.

The relevant data for the estimation (total outstanding and foreign holdings of local-currency government debt securities) come from national data sources, as discussed in Arslanalp and Tsuda (2014). Figure 7 provides a summary of the data as of end-2014. Figure 8 provides the country weights $\left(w_{i, t}\right.$ and $\left.W_{i, t}\right)$ as of end-2014.

Table 5. Sample of Countries

\begin{tabular}{cccc}
\hline Asia & Latin America & EMEA-EU & EMEA-Non EU \\
\hline China & Brazil & Czech Republic & Israel \\
India & Colombia & Hungary & Russia \\
Indonesia & Mexico & Poland & South Africa \\
Korea & Peru & Romania & Turkey \\
Malaysia & & \\
Thailand & & \\
Note: Countries that are not in the J.P. Morgan GBI-EM Global Diversified index are shown in \\
italics. EMEA = Europe, Middle East, and Africa.
\end{tabular}

Figure 7. EM Local-Currency Government Debt Markets, End-2014

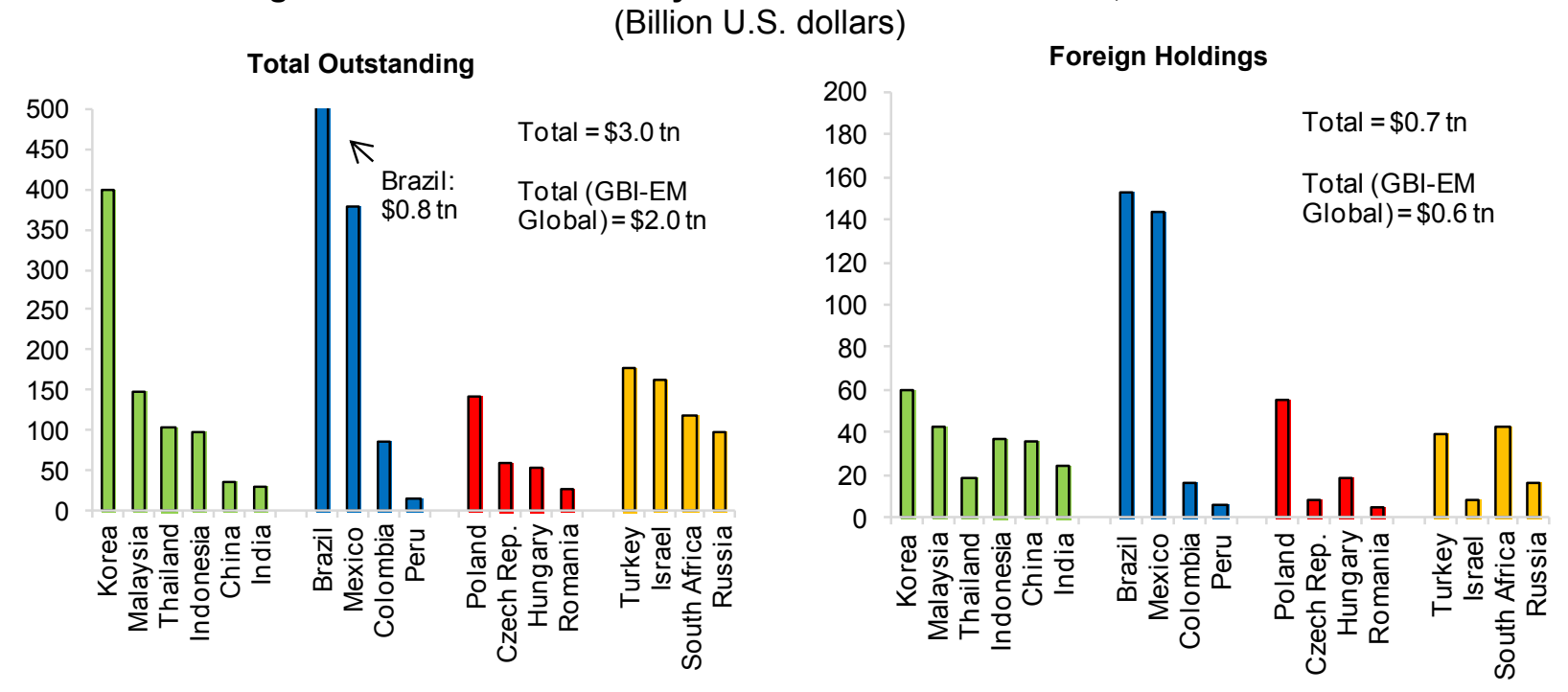

Sources: National authorities and authors' calculations.

Note: For China and India, outstanding amount reflects the "investable" portion of the market given foreign investment quotas.

\footnotetext{
${ }^{8}$ Chile, Nigeria, and the Philippines are also part of the GBI-EM Global Diversified index but are not included in the sample because monthly data on foreign holdings of local-currency government bonds are not available for them. They account for only 2 percent of the GBI-EM Global Diversified index as of end-2014.

${ }^{9}$ The Czech Republic, Israel, and Korea are now classified as advanced economies by the World Economic Outlook of the IMF, but traditionally seen as EMs by investors. Indeed, all three countries were initially part of the J.P Morgan GBI-EM index when it was launched in 2005. They left the index when they no longer met the low- or middle-income per capita criterion.
} 
Figure 8. EM Local-Currency Government Bond Markets: Country Shares, End-2014 (Percent)

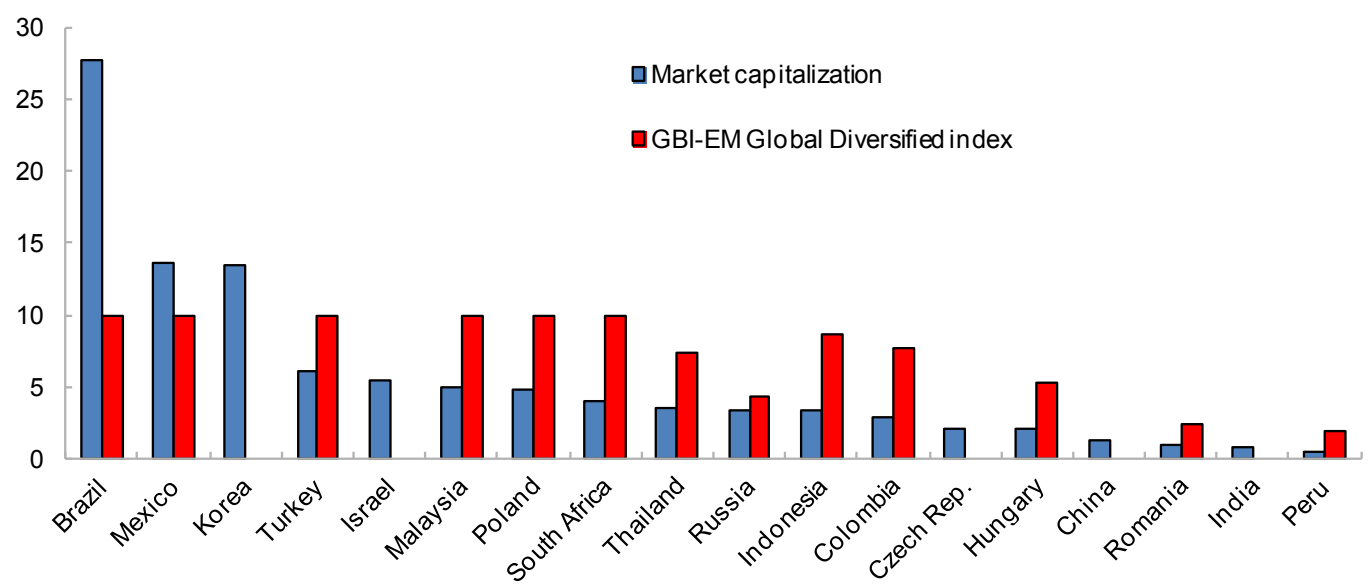

Sources: J.P. Morgan and authors' estimates.

Note: For China and India, outstanding amount reflects the "investable" portion of the market given foreign investment quotas.

The results of the regression analysis for $a_{t}$ and $b_{t}$ are summarized in Figure 9. The results suggest that the pool of benchmark-driven investors in EM local currency debt markets was around $\$ 240$ billion at end-2014, down from a peak of $\$ 300$ billion just before the taper tantrum of May 2013. The empirical estimates - both in levels and trends — are broadly in line with the J.P. Morgan survey results on the use of GBI-EM indices, and the EPFR Global data on assets under management by EM local currency bond funds, including both mutual funds and ETFs (Figure 10, left and right panels). ${ }^{10}$

Figure 9. Foreign Holdings of EM Local-Currency Government Debt, 2010-15Q2 (Billion U.S. dollars)

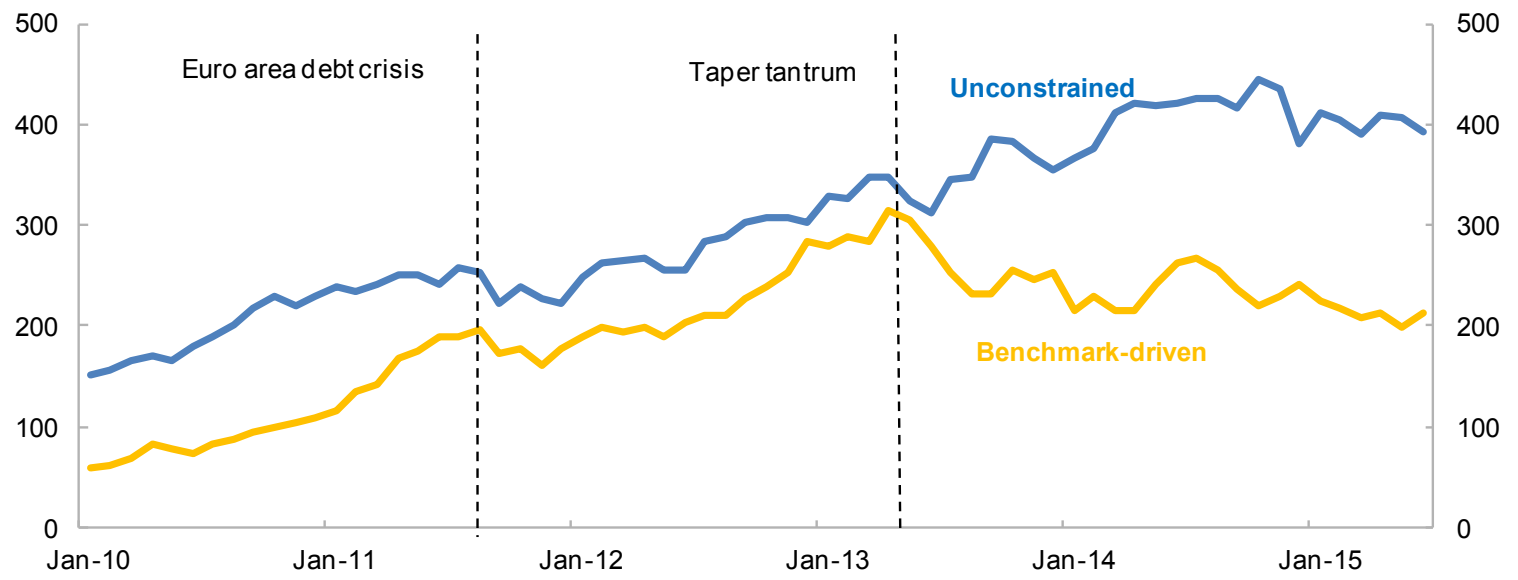

Sources: Authors' estimates.

Note: The benchmark-driven investor base is estimated based on the approach proposed by Balston and Melin (2013). The euro area crisis is indicated by the ECB President's speech in July 2012 pledging to do "whatever it takes" to preserve the euro.

${ }^{10}$ Not surprisingly, the empirical estimates are somewhat higher than the J.P. Morgan survey. The difference likely reflects assets benchmarked to other EM bond indices. Presumably, these would be reflected in the empirical estimates given the large country overlap between among EM local bond indices (Box 1). They are also higher than the EPFR data as the latter only include mutual funds and ETF holdings, while the empirical estimate would also include holdings through other investment vehicles, such as separate managed accounts. 
Figure 10. Comparison of Empirical Estimates with Other Data Sources (Billion U.S. dollars)
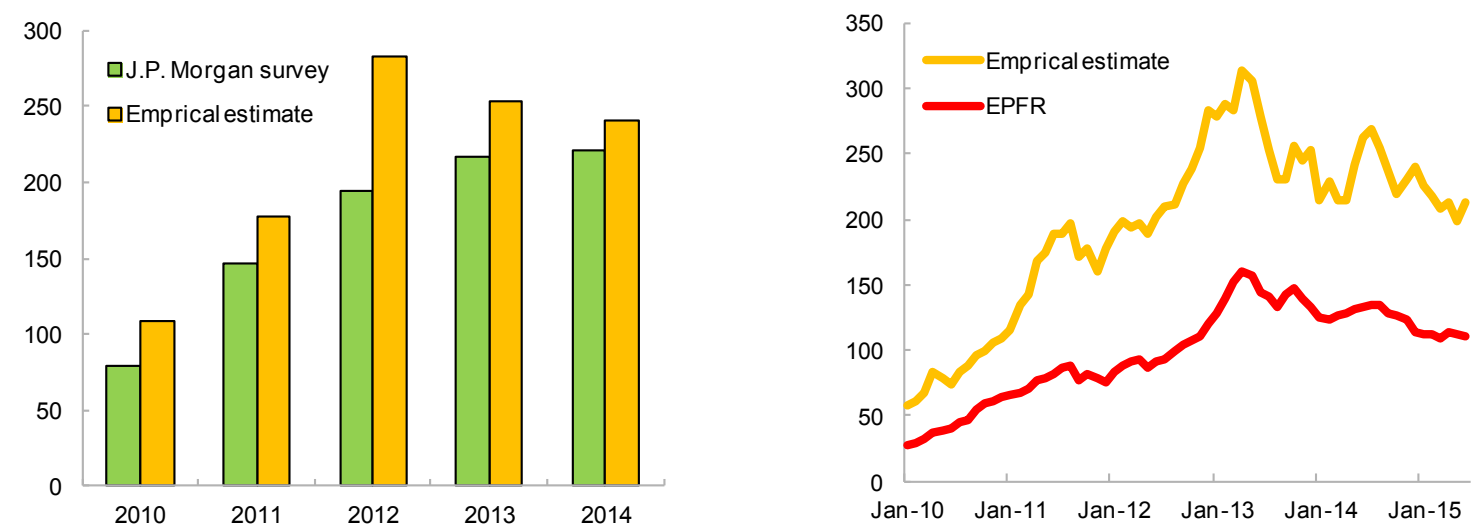

Sources: EPFR Global, J.P. Morgan (2014), and authors' calculations.

Note: The empirical estimates are based on the approach proposed by Balston and Melin (2013). EPFR data show assets managed by EM local currency bond funds (mutual funds and ETFs) globally.

Figure 11 shows that the composition of benchmark-driven and unconstrained investors varied over time and across countries during January 2010-June 2015 (Annex Figure 1 provides the country-specific time series). At its peak - just before the taper tantrumbenchmark-driven investors accounted for close to half of total foreign holdings in EMs (Figure 11, left panel). Moreover, for some countries, such as Colombia, Peru, and Romania, they still represent the bulk of the foreign investor base (Figure 11, right panel).

Figure 11. EM Local-Currency Government Debt Markets: Type of Foreign Holdings (Percent of total foreign holdings)

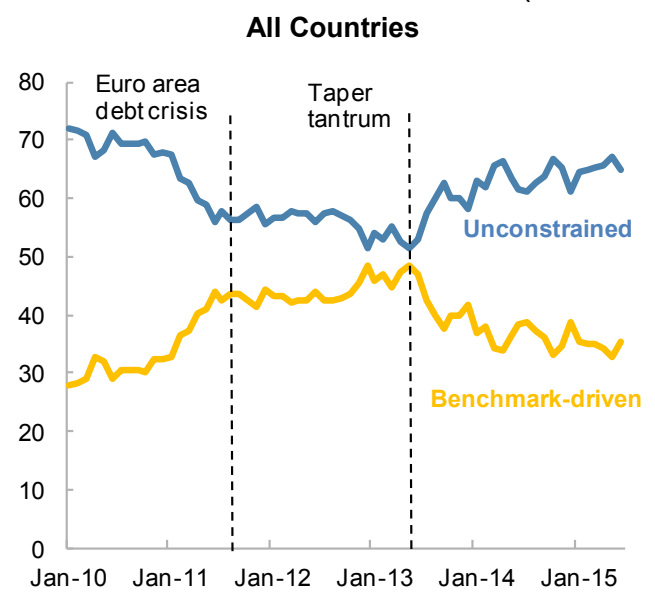

By Country, end-2014

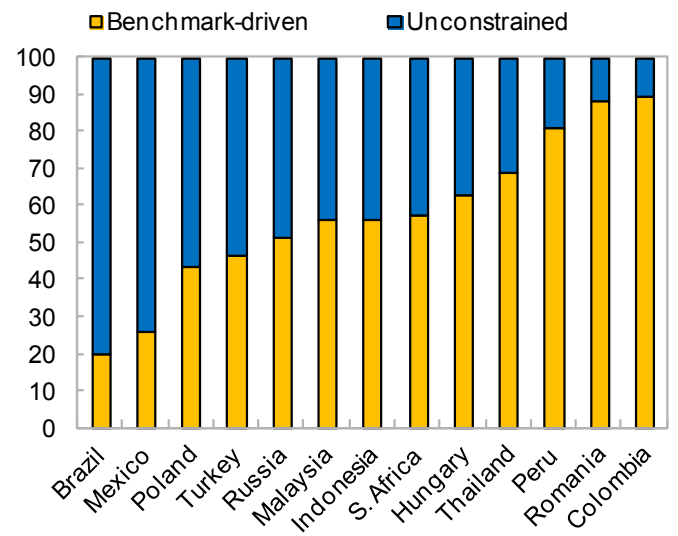

Source: Authors' calculations.

Note: The benchmark-driven investor base is estimated using the approach proposed by Balston and Melin (2013).

Two possible explanations could describe the country differences. First, on the supply side, countries that have relatively large and liquid government bond markets may attract more unconstrained investors (e.g., Mexico, Brazil, and Poland), while investment in relatively small markets may attract investors only when a third party (that is, an index provider) gives the green light for investment. Indeed, Figure 12 (left panel) shows that the share of benchmark-driven investors is inversely related to market size. Second, on the demand side, countries that become exposed to outflows from unconstrained investors, because of countryspecific shocks, may end up having a higher presence of benchmark-driven investors. 
Figure 12. EM Local-Currency Government Debt Markets: Selected Indicators
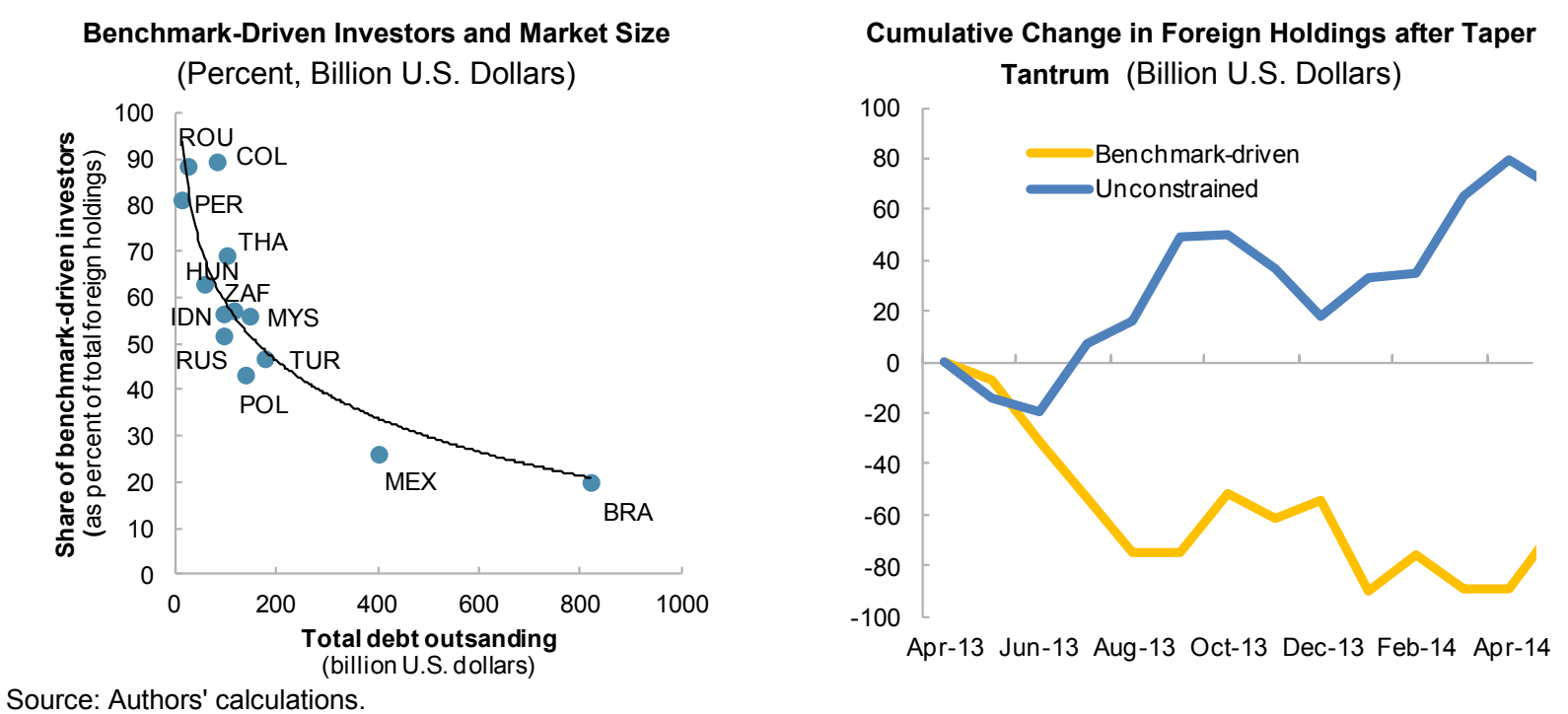

\section{KEY IMPLICATIONS}

Four key implications follow from these results:

First, by linking countries in the same portfolio, benchmarks can trigger correlated portfolio flows, connecting countries that might otherwise be disconnected through country fundamentals. Indeed, while all investors reduced exposure to EMs in the initial phase of the May 2013 taper tantrum, benchmark-driven investor outflows lasted for about one year after the event (Figure 12, right panel). This result suggests that having liquidity buffers can be useful even for countries with strong fundamentals (IMF, 2015), especially in countries where benchmark-driven investors have a large presence (Figure 11).

Second, as the share of benchmark-driven investors in EM local bond markets has fallen since the taper tantrum, it is increasingly important for EMs to maintain strong domestic policies, as unconstrained investors have more latitude to switch from one country to another based on perceived changes in risk-return characteristics.

Third, given that major EM local currency bond indices (including the GBI-EM) do not require a minimum credit rating for inclusion (Box 1), the presence of ratings-sensitive investors in the benchmark-driven investor base may be limited. In contrast, unconstrained investors could be quite sensitive to credit-rating changes, further highlighting the previous point above. Hence, safeguarding investment grade status may be important, especially for countries with a large unconstrained investor base.

Finally, the results also have implications for countries that are not yet included in EM local currency bond indices. In particular, our estimate of the benchmark-driven investor base can provide some basis to assess broadly how much capital these countries may expect to receive once included in flagship EM local bond indices. 


\section{Conclusion}

Various approaches discussed in the paper suggest that about $\$ 200-\$ 250$ billion of foreign investments in EM local currency government bonds were benchmark-driven as of end-2014, representing more than one third of total foreign holdings ( $\$ 600$ billion). The prominence of these investors grew until it reached a peak before the May 2013 taper tantrum (when they represented nearly one-half of total foreign holdings). It appears that the taper tantrum was an important milestone in the risk sentiment towards EMs, at least for benchmark-driven investors. A possible explanation is that the impact of exchange rate volatility became more important for these investors after May 2013, when they realized that the Federal Reserve may reduce the scale of its asset purchases sooner than previously expected (Gadanecz et al., 2014). As a result, investors may have turned from broad asset allocation strategies to country selection. This is in line with studies that show that EM investors have since become more differentiating (Sahay et al., 2014). Nevertheless, given their size, benchmark-driven investors are still likely to play an important role in driving portfolio flows to emerging markets, especially in countries where they have a large presence. 
Annex Figure 1. EM Local-Currency Government Debt: Type of Foreign Holdings, 2010-15Q2 (Billion local currency)

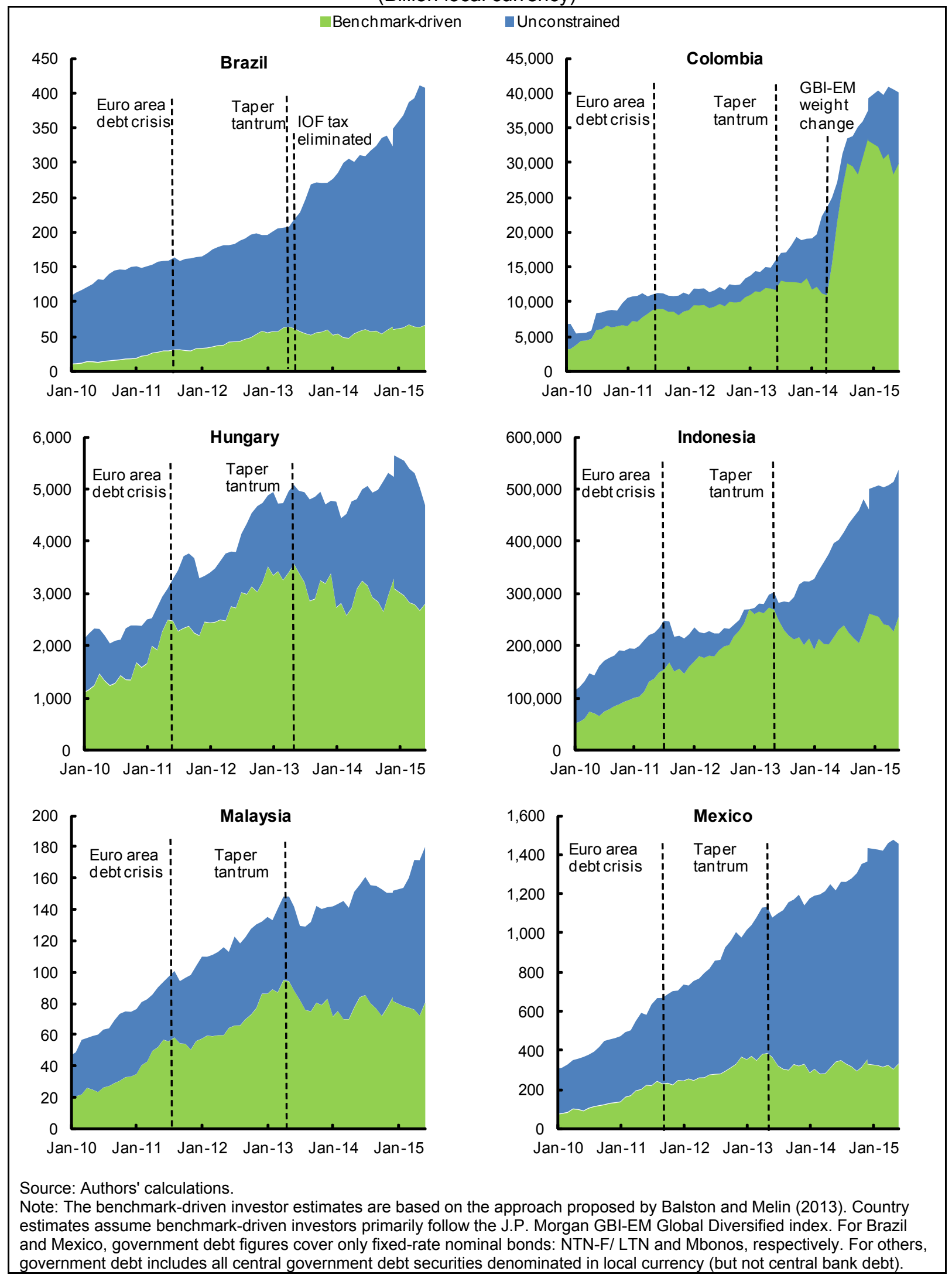


Annex Figure 1. EM Local-Currency Government Debt: Type of Foreign Holdings, 2010-15Q2 (continued)

(Billion local currency)

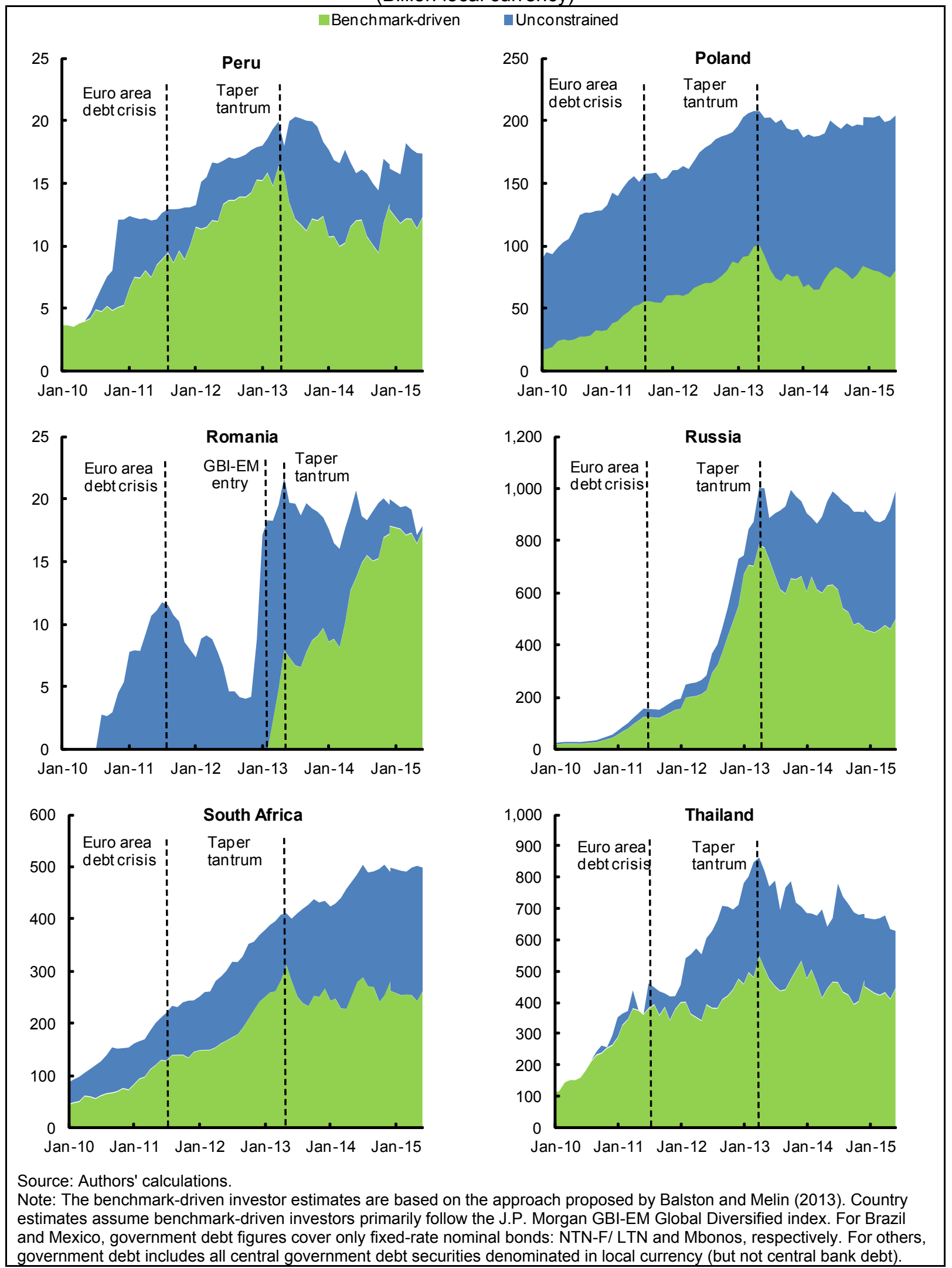


Annex Figure 1. EM Local-Currency Government Debt: Type of Foreign Holdings, 2010-15Q2 (concluded)

(Billion local currency)

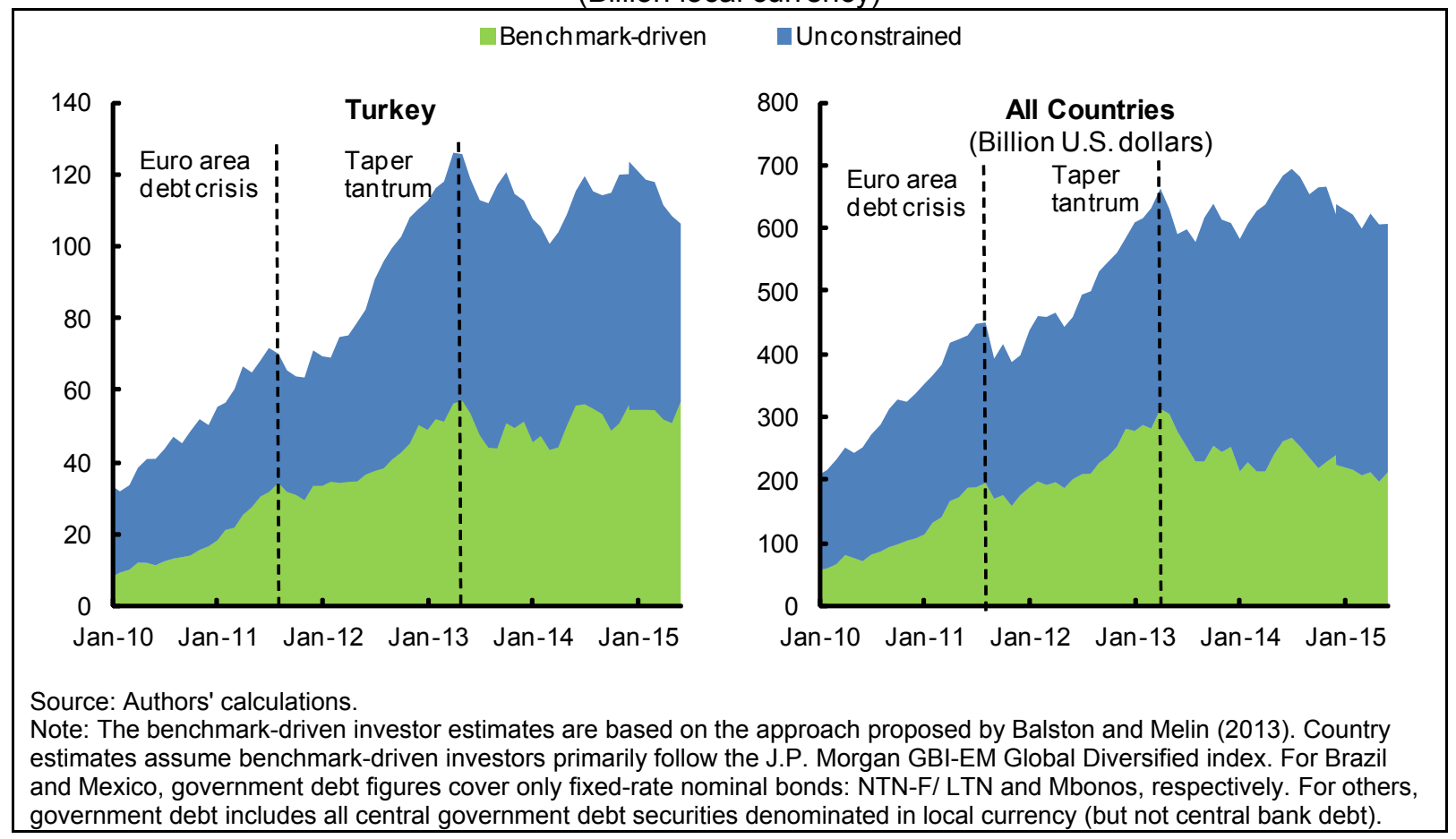




\section{References}

Arslanalp, S. and T. Tsuda, 2014a, "Tracking Global Demand for Advanced Economy Sovereign Debt," IMF Economic Review, Vol. 62, Issue 3, pp. 430-464.

Arslanalp, S. and T. Tsuda, 2014b, "Tracking Global Demand for Emerging Market Sovereign Debt,” IMF Working Paper 14/39. Washington: International Monetary Fund.

Balston, M. and L. Melin, 2013, "Foreign Demand for EM Local Currency Debt," Deutsche Bank EM Monthly: Diverging Markets, December 2013.

Broner, F., G. Gelos and C. Reinhart, 2006, "When in Peril, Retrench: Testing the Portfolio Channel of Contagion," Journal of International Economics, 69(1): 203-30.

Cerutti, E., S. Claessens, and D. Puy, 2015, "Push Factors and Capital Flows to Emerging Markets: Why Knowing Your Lender Matters More Than Fundamentals," IMF Working Paper 15/127, Washington: International Monetary Fund.

Coval. J., and E. Stafford, 2007, “Asset Fire Sales (and Purchases) in Equity Markets,” Journal of Financial Economics 86, no.2, 479-512

Cremers, M and A. Petajisto, 2009, "How Active is Your Fund Manager? A New Measure That Predicts Performance," Review of Financial Studies, vol 22(9), pp 3329-65.

Gadanecz B., K. Miyajima, and C. Shu, 2014, "Exchange Rate Risk and Local Currency Sovereign Bond Yields in Emerging Markets," BIS Working Papers No 474, December 2014

Gelos, G. 2013, "International Mutual Funds, Capital Flow Volatility, and Contagion-A Survey," in The Evidence and Impact of Financial Globalization, edited by G. Caprio, T. Beck, S. Claessens, and S. Schmukler: 131-43.

International Monetary Fund, 2014, "How Do Changes in the Investor Base and Financial Deepening Affect Emerging Market Economies?” Global Financial Stability Report: Chapter 2. Washington, April.

International Monetary Fund, 2015, "Balance Sheet Analysis in the Fund: Reference Note," IMF Policy Paper, July 13, 2015. Washington, July

Jotikasthira, C., C. Lundblad, and T. Ramadorai, 2012, "Asset Fire Sales and Purchases and the International Transmission of Funding Shocks," Journal of Finance 67:6, 20152050

J.P. Morgan, 2014, Local Markets Guide: Emerging Market Research, $10^{\text {th }}$ Edition, September, 2014. 
Koepke, R., 2015, "What Drives Capital Flows to Emerging Markets: A Survey of the Empirical Literature," IIF Working Paper, Washington, April.

Levy-Yeyati, E. and T. Williams, 2012, "Emerging Economies in the 2000s: Real Decoupling and Financial Recoupling," Journal of International Money and Finance, Volume 31, Issue 8, December 2012.

Miyajima, K. and I. Shim, 2014, “Asset Managers in Emerging Market Economies,” BIS Quarterly Review, September, 2014.

Raddatz, C., S. Schmukler, and T. Williams, 2015, "International Asset Allocations and Capital Flows: The Benchmark Effect.” HKIMR Working Paper No. 04/2015.

Sahay, R., V. Arora, T. Arvanitis, H. Faruqee, P. N'Diaye, T. Mancini-Griffoli, and an IMF Team, 2014, "Emerging Market Volatility: Lessons from the Taper Tantrum." IMF Staff Discussion Note SDN 14/09, Washington: International Monetary Fund.

Sienaert, A., 2012, "Foreign Investment in Local Currency Bonds: Considerations for Emerging Market Public Debt Managers," World Bank Policy Research Working Papers No. 6284, Washington: The World Bank.

Stein, J., 2013, “Overheating in Credit Markets: Origins, Measurements, and Policy Responses," Speech at the Federal Reserve Bank of St. Louis, February 7. 